\title{
Anne Scott Sørensen, Ole Martin Høystad, Erling Bjurström \& Halvard Vike: Nye kulturstudier. Teorier og temaer. København: Tiderne Skifter. 2010.
}

\author{
Britta Timm Knudsen
}

MedieKultur 2011, 50, 202-204

Published by SMID | Society of Media researchers In Denmark | www.smid.dk The online version of this text can be found open access at www.mediekultur.dk

Bogen, der betegner sig selv som en introduktion til de nye kulturstudier, er en moppedreng på 369 sider, hvortil kommer litteraturliste og register. Bogen er en revideret dansk version af den norske udgave fra 2008, oversat fra norsk af Joachim Wang. Forfatterkollektivet kommer fra det gamle Skandinavien og har med denne bog sat sig for at lave den første introduktion i Norden af cultural studies, der opstod i midten af det 20. århundrede i Storbritannien som en interdisciplinær institutionskritisk kulturdisciplin i grænsefeltet mellem humaniora og samfundsvidenskab. Bogen vil give et bud på "hvad de nye kulturstudier kan være, både som et undervisnings- og et forskningsfelt" (p. 12). Så man kan både hilse denne noget forsinkede introduktion velkommen i Norden i erkendelse af, at cultural studies aldrig helt er slået igennem på vore breddegrader, og man kan karakterisere de nye kulturstudier som 'yesterday's news', da de i international sammenhæng har været gangbare de seneste 50 år.

Herfra skal både lyde et rungende velkommen til cultural studies i Norden og et anerkendende nik i forhold til viljen til at forankre disciplinen teoretisk og metodologisk, således at den holdes fri af kritikken om, at cultural studies er alt godt fra havet, eller at kulturanalyse er så generel en betegnelse for det, alle humanister bedriver, at der ikke kan siges noget specifikt herom. Men - og det er et seriøst men: moppedrengen om de nye kulturstudier undgår desværre ikke betegnelsen 'yesterday's news', forfatterne sætter sig mellem for mange stole og undlader at foretage de nødvendige valg i forhold til at gøre bogen til en brugbar introduktion til aktuel kulturanalyse. Nye kulturstudier har en encyklopædisk tilgang, i og med at forfatterne laver deres egne små introduktioner til velkendte forfat- 
terskaber og til tematiske felter. Problemet er bare, at selv det encyklopædiske har mangler. Således er udvalget af nordiske miljøer og værker, der bliver betragtet som en del af de nye kulturstudier, ret vilkårligt: André Jansson (medieforsker fra Karlstad) nævnes som repræsentant for mediegeografi, mens stærke miljøer som Service Management i Helsingborg og kommunikation og oplevelsesøkonomi på Aalborg Universitet, der hver især har markeret sig stærkt inden for oplevelsesøkonomi og forbrugerstudier, forbigås. Dette er ikke sagt for at kunne finde fem fejl, men mere for at påpege, at selv når man forsøger at være bredt favnende, er der huller, og det vil der altid være.

Et alternativ til den encyklopædiske tilgang kunne have været at kortlægge cultural studies-miljøer i Norden for at beskrive, hvordan det gøres nu dér; et andet alternativ kunne have været at vælge aktuelle temaer ud og med udgangspunkt i disse at stille de 'gamle' teoretikere i et nyt lys og derudfra udvinde stærke begreber og analysestrategier. Det ville have været interessant at spørge, hvad der sker med det klassiske cultural studies minoritetsperspektiv, som vi ser afspejlet i begrebsparrene majoritet-minoritet og hegemoni-marginalitet, når studierne bliver til forbrugs- og oplevelsesstudier. Forsvinder de helt, eller stiller de sig på andre måder?

Bogen indledes med en begrebsafklaring af kulturbegrebet. Udmærket tænkt, men symptomatisk munder kapitlet ud i en model af det komplekse kulturbegreb (p. 44), der med sine mange ben: haven, gøren, kunnen og væren, mellem ontologi og epistemologi, universalitet og relativitet, nærmer sig en borgesiansk 1:1-gengivelse af verden, der ikke gør læseren klogere på, hvordan verden kan læses anderledes lige nu. Efterfølgende er der et kapitel om de teoretiske forfædre fra strukturalisterne til poststrukturalisterne. Her forankres cultural studies i marxisme, semiotik og psykoanalyse helt efter bogen. Frankfurterskolens kritiske teori får deres, populær- og hverdagskulturelle studier nævnes, poststrukturalismen præsenteres igennem Butler og Derrida, og konstruktivisme og nypragmatik præsenteres ikke særligt oplagt gennem Bourdieu og Latour. I en parentes kan det bemærkes, at disse to er særligt kendte gennem Latours positionering af sin egen sociologi som én, der undersøger, hvordan det sociale overhovedet kommer til syne (emergens) over for Bourdieus analyse af det sociale som noget, der allerede eksisterer. Hvorfor kapitlet skal benævnes "konstruktivisme" er pudsigt, eftersom man vel ikke kan kalde Bourdieu konstruktivist (det er Butler til gengæld), og Latour fremhæver sig selv som postkonstruktivist.

Hvorom alting er, i dette kapitel gentages kendte pointer og introducerende bemærkninger til skoler og forfatterskaber, som er set før. En fremgangsmåde, der anvendes hele bogen igennem: Hver gang en teoretiker nævnes, introduceres vedkommende på ny. Dette gælder Kant, Bourdieu, Foucault, Giddens, Beck, Baudrillard, Debord m.fl. Man spørger sig selv hvorfor? Disse forfatterskaber er kendte og særdeles velintroducerede i både glimrende engelske og skandinaviske readers, antologier og artikler, så hvis man skriver om dem nu, må det ske i en ny indramning, der aktualiserer læsningen af dem. Både for studerende og forskere. Ellers ville et mere oplagt valg have været at samle oversættelser af gode introduktioner til forfatterskaberne. 
Bogen fortjener til gengæld ros for sit metodeafsnit, som mageligt kunne have været længere. Der nævnes tre meget generelle tilgange: den historiske tilgang, den tekst- og diskursanalytiske tilgang og den etnografiske feltstudiemetode. Dette tenderer igen til at blive for generelt, men det gode i dette afsnit er de ansatser til helt konkrete greb, der påvises via begreber som for eksempel interpellation-aktualisering, encoding-decoding og diakronisynkroni, og diskursanalysen af Natasjas sang "Gi' os Danmark tilbage" er eksemplarisk. Jeg ville gerne have haft, at der havde været introduceret flere af de begreber, som er aktuelle for kulturanalysen, for eksempel begreber som remediering, hybridisering, mimicry. Gerne med konkrete anvisninger på, hvorledes disse kan fremlæses.

Resten af bogen er viet tre temaer, som bogens forfattere har peget ud som kendetegnende for aktuelle reformuleringer af cultural studies: identitet, globalisering og multikulturalisme, smag, livsstil og forbrug samt krop og oplevelser, natur og landskaber. Identitet og multikulturalisme må siges at være kernebegreber for en cultural studies-tilgang og har været det siden disciplinens opkomst. Her er der grund til at være kritisk: Kapitlet præsenterer et meget blegt genskin af hele denne problematik, der er introduceret i globaliserings- og minoritets-, køns- og postkoloniale samt postnationale studier verden over. I kapitel 5, "Smag, livsstil og forbrug", foretages en tour de force fra Kants sensus communis over Bourdieus distinktionsstudier til Veblen, Baudrillard, Debord, Pine og Gilmore, Schulze (Oplevelsessamfundet, 1992) og Daniel Miller. Her bliver det igen tydeligt, at det er viljen til at legitimere de nutidige analysestrategier i cultural studies historisk, der sejrer over evnen til at rammesætte de nye kulturstudier på ny.

I slutkapitlet er der gode ansatser til spændende perspektiveringer i forhold til materiel kultur, nyere æstetisk teori (Schusterman) og Lash og Lurys Global Culture Industry med dennes fokus på begreber som events, intensitet, tingsliggørelse og følelse. Det ville læseren gerne have set noget mere af i stedet for at blive trukket igennem forskellige epokers forskellige naturopfattelser endnu engang for prins Knud.

Så altså: Nye kulturstudiers forfattere skal have ros for initiativet til at tage cultural studies-traditionen alvorligt og invitere den ind i det gode videnskabelige selskab i Norden 50 år efter disciplinens opkomst. Hvilket siger mere om Norden end om bogen. Til gengæld skal bogen have ris for sin encyklopædiske vilje til introduktion til forfatterskaber og felter, der allerede i så rigeligt mål er introducerede, og for sin manglende evne til at rammesætte på ny.

Britta Timm Knudsen Lektor, ph.d. Nordisk Institut Aarhus Universitet norbtk@hum.au.dk 